DOI: $10.5937 / \mathrm{MegRev} 2103267 \mathrm{~B}$

Original scientific paper

Received 20.11.2020.

Approved 18.12.2020.

\title{
CHINESE DIASPORA IN SERBIA
}

\begin{abstract}
The focus of the paper is better understanding of the experiences of the Chinese diaspora who lives in Serbia, their perception of Serbia as their destination country and their view on the economic environment and the quality of life in Serbia. The research was conducted in the period from June to December 2017, and included 52 representatives of Chinese diaspora in Serbia. As a method of research semi-structured interview was used. Results show that representatives of the Chinese diaspora do not recognize Serbia as a very favorable business destination and most of them see their stay in Serbia as temporary and dependent on economic conditions.
\end{abstract}

Keywords: Chinese Diaspora, Serbia, diaspora experiences, relationship with homeland.

* Associated Professor, University Union Nikola Tesla, Belgrade, Serbia; ibozicmiljkovic@gmail.com

** Lecturer, School of Business, Novi Sad, Serbia, e-mail: dr.ana.jovicic@gmail.com 


\section{Introduction}

Among developing countries, decades ago, modern China deserved special attention from the perspective of economic growth, as well as role in the global economy. As the world's most populated country (1.3 billion people, a huge internal market and a great potential for development), it can in the future disturb the world's economic power. The great political and economic reversal of China and its success in the 1980s's development has improved its position in the global economy and strengthened its political influence in the world in the ranks of those of the United States, the EU and Japan. The key role in China's economic development was its specific „open door policy”. This policy has drawn the attention of developed countries to a huge market with great human and economic potential in which it is worth investing and where the rate of return on investment is high. In a short period of time, there was a sudden inflow of foreign capital, and Chinese immigrants particularly highlighted in the mass of investors.

One of the main characteristics of the Chinese Diaspora is that they remain loyal to their homeland, maintain their customs and traditions wherever they are, as well as contact with their families and friends living in China. The basis of this model of the Chinese diaspora lies in the fact that this diaspora consists of people whose motivation to leave China was partly motivated by economic factors, and partly related to disagreements with certain policies that the Chinese authorities led during the second half of the 20th century. Such a diaspora had a very positive reaction to the new Chinese open door policy to the world. The Chinese Diaspora has become one of the leading business partners with its homeland, participating in the investment and commissioning of its rapidly developed economic growth of significant funds, its technology, knowledge and skills. In the beginning of the 21 st century, some of the diaspora returned to China and those who remained abroad continued building tight connections with their homeland, investing their capital in the development of various industries and services, developing various forms of business and improving their business cooperation between their companies in the destination countries as well as in China.

According to the numerosity, China's diaspora is the fourth largest diaspora in the world. It has 9,5 million members. In front of China are: India with 15.6 million, Mexico with 12.3 million and Russia with 10.6 million registered diaspora members ${ }^{1}$. Geographical distribution of Chinese diaspora, its demographic and economic structure are a fluid category that has changed over the centuries and will continue to change in the future. What remains and survives in all historical conditions, despite all the changes, is the close link between the Chinese Diaspora and its homeland, which is a positive example in the global context.

A certain number of Chinese diaspora lives and works in Serbia. Serbia is also a country with a large diaspora in Europe and the world, but, unlike China,

UN International Migration Report 2018: Highlights, United Nations 2019, pp.18 
but had not succeeded in forming tighter economic relations with its diaspora neither obtaining it as an economic partner over a period of several decades.

In this sence, the experiences of China with its diaspora are valuable to Serbia and it is also very important to consider the way the Chinese diaspora perceives Serbia as a destination to live and develop business.

\section{Literature Review}

The phenomenon of the Chinese diaspora and its very successful economic cooperation with their homeland is the subject of the study of many Chinese authors as well as authors in other parts of the world where the Chinese diaspora is present. ${ }^{2}$ These and other authors point to the multidimensional and mutually positive attitude of the Chinese diaspora and its homeland, based on strong patriotism and the desire to preserve and promote Chinese culture and tradition in any part of the world. Such a relationship generates both mutual economic gains. On the one hand, China, with its diaspora, is developing a partnership relationship that results in economic benefits, largely through remittances. According to the quantity and value of remittances sent to their country, China has been the world's number one in the world for decades. ${ }^{3}$ In this relationship, cash remittances are treated as investment capital and, like any other form of capital, are motivated by profit. On the other hand, the Chinese diaspora has an interest in cooperating with the homeland. This interest is realized through the long-term and constant development and improvement of various forms of cooperation with the parent in different areas. Geographically, the Chinese diaspora spreads around the world. ${ }^{4}$ They are mainly present in trade, manufacturing, services (catering, construction), but also present in scientific institutes, universities and research centers around the world. ${ }^{5}$ The migration wave from China in the early nineties brought a large number of immigrants to Serbia where they started

2 D. L.. Poston and D. Yaukey, (1992): The Population of Modern China. Springer Science \& Business Media, New York; L.Pann, (1994): Sons of the Yellow Emperor: A History of the Chinese Diaspora. Kodansha America, New York. X. Biao, (2003): „Emigration from China: A Sending Country Perspective “. International Migrations, 41(3); G. Shixu, (2011): „The contribution of overseas Chinese to China's development “, in Q. Jin, Z. Yudong, L. Kereng and L. Minghuan (eds.), Annual Report on Overseas Chinese Studies, Social Sciences Academic Press, Beijing, pp. 51-84ss.

3 International Organization for Migrations, Migrations Initiative 2016, https://publications.iom.int/system/files/migration_initiatives2016.pdf; National Bureau of Statistics of China, https://data.stats.gov.cn/english/? $\mathrm{cn}=\mathrm{A} 01$

4 L. Pann, (2006): The Encyclopedia of the Chinese Overseas, Singapore: Didier Millet edition.

5 F. Pastore and E. Castagnone, (2011): „Studiare L' Imprenditoria Cinese Oltre i Luoghi Comuni. In Camera di Commercio in Torino “. Diventare Laoban: Lavoro Autonomo Percorsi Imprenditoriali e Progetti Migratori dei Cinesi in Italia e a Torino, Camera di Commercio, Torino, pp.3-15. 
operations in the trade and fast food production sector. The official database of Chinese residents in Serbia does not exist and the data varies depending on the source and purpose (APR http://www.apr.gov.rs, Đorđević, 2006). A number of Serbian authors analyzed the economic wonder of China and their rapidly growing economy at their global level. ${ }^{6}$ However, there are not enough scientific papers on the position of the Chinese in Serbia, their connection with the homeland and their perception of Serbia as a destination country.

\section{The Chinese Diaspora}

The history of the creation of the Chinese diaspora is over a century long. Today, its diaspora is concentrated in about fifty countries around the world (Pan, 2006: 86, Poston \& Wong, 2016: 361). Over the decades and centuries, depending on social and economic conditions, the size, as well as the age and the education structure of the diaspora has been changing. The reasons for the Chinese residents to emigrate thir homeland were various: applying for a political asylum, improving their education, easier employment and higher income abroad and disagreement with numerous policies imposed by China, particularly during the 20th century, such as the restrictive birth control policy (Biao, 2003: 23; Iredale \& Guo 2015: 93). Until the half of the previous century, the Chinese around the world were being recognised as merchants of cheap products: clothes, shoes, toys, as well as promoters of the Chinese cuisine through their restaurants and fast food facilities opened around the world. Today the situation is quite different. The structure of the today's Chinese diaspora consists of a large number of experts and highly educated people who are involved in various activities and spheres of economic life of the destination countries (Pastore \& Castagnone, 2011).

According to data from the table, traditionally most of the Chinese diaspora is on the territory of southeast Asia. They mainly inhabit three autonomous administrative divisions: Hong Kong, Taiwan and Makao, which were known as areas of fast industry development in the need of the 20th century. ${ }^{7}$ Between 2007 and 2011, contrary to the growing population trend of the Chinese residents from the previous several decades, their number declined in Asia. ${ }^{8}$ This

$6 \quad$ P. Simić, (2003): Kina: kratka istorija, Nea, Beograd; D. Mitrović, (2008): Kinesko ekonomsko čudo - prva dekada reformi. IPS, Beograd. M. Đorđević and S.Stojiljković, (2013): „Ekonomska politika i javni dug u vreme globalne krize: preporuke vodećih ekonomista današnjice “, in V. Leković (eds.), Institucionalne promene kao determinanta privrednog razvoja Srbije, Ekonomski fakultet, Kragujevac, pp. 243-258.

$7 \quad$ H. You-tien, (2003): "Ethnic identity and business solidarity: Chinese capitalism revisited", in L. J. C. Ma, and C. Cartier (eds), The Chinese Diaspora: Space, place, mobility and identity. Boulder, Colorado: Rowman and Littlefield, pp. 228.

$8 \quad$ M. Zhou and G. Benton, (2017): "Intra-Asian Chinese Migrations: A Historical Overview". In M. Zhou (eds.), Contemporary Chinese Diasporas. Palgrave Macmillan, UK, pp.20-21. 
was partly due to global economic crisis, which affected the Chinese economy most dramatically in the south of China, within the areas where the capacities of export-oriented light industry are concentrated. Thousands of companies went out of business, ten thousands of workers were fired and several millions of workers - migrants, returned to their provinces. ${ }^{9}$

Table 1 Number of overseas Chinese in the World and by continent between 1948 and 2011

\begin{tabular}{|l|c|c|c|c|c|c|c|c|}
\cline { 2 - 9 } \multicolumn{1}{c|}{} & $\mathbf{1 9 4 8}$ & $\mathbf{1 9 6 0}$ & $\mathbf{1 9 7 0}$ & $\mathbf{1 9 8 0}$ & $\mathbf{1 9 9 0}$ & $\mathbf{2 0 0 0}$ & $\mathbf{2 0 0 7}$ & $\mathbf{2 0 1 1}$ \\
\hline Asia & 8.380 & 14.880 & 18.343 & 24.764 & 32.288 & 32.942 & 35.481 & 29.597 \\
\hline America & 209 & 407 & 711 & 1.333 & 3227 & 4.333 & 6.300 & 7.503 \\
\hline Europe & 54 & 16 & 112 & 622 & 770 & 1.454 & 2.152 & 2.016 \\
\hline Oceania & 64 & 42 & 68 & 176 & 374 & 786 & 950 & 963 \\
\hline Africa & 15 & 41 & 59 & 77 & 108 & 244 & 550 & 249 \\
\hline Total & 8.722 & 15.386 & 19.293 & 26.972 & 36.767 & 39.759 & 45.430 & 40.328 \\
\hline
\end{tabular}

Source: *Data for the period 1948-1980: D. L. Poston and Y. Mei-Yu (1992): The Distribution of Overseas Chinese, in D.L. Poston and D. Yaukey, The Population of Modern China. Springer Science \& Business Media, New York, pp. 127.

** Data for the period 1990-2011: D. L. Poston and J. Wong (2016). “The Chinese Diaspora: The Current Distribution of the Overseas Chinese Population". Chinese Journal of Sociology 2(3), pp.357.

Table 2: Global growth distribution of the Overseas Chinese population since 1948 to $2011(\%)$

\begin{tabular}{|l|c|c|c|c|c|c|}
\cline { 2 - 7 } \multicolumn{1}{c|}{} & $\mathbf{1 9 4 8 - 1 9 6 0}$ & $\mathbf{1 9 6 0 - 1 9 7 0}$ & $\mathbf{1 9 7 0 - 1 9 8 0}$ & $\mathbf{1 9 8 0 - 1 9 9 0}$ & $\mathbf{1 9 9 0 - 2 0 0 0}$ & $\mathbf{2 0 0 0 - 2 0 1 1}$ \\
\hline Asia & 0,8 & 0,2 & 0,4 & 0,3 & 0,02 & $-0,1$ \\
\hline America & 0,9 & 0,7 & 0,9 & 1,4 & 0,3 & 0,7 \\
\hline Europe & $-0,7$ & 6,1 & 4,5 & 0,2 & 0,9 & 0,4 \\
\hline Oceania & $-0,3$ & 0,6 & 1,6 & 1,1 & 1,1 & 0,2 \\
\hline Africa & 1,7 & 0,5 & 0,3 & 0,4 & 1,3 & 0,02 \\
\hline Total & 0,8 & 0,3 & 0,4 & 0,4 & 0,1 & 0,01 \\
\hline
\end{tabular}

Calculated by the authors based on data from the Table 1

Based on the present data a projection of the fluctuation of the Chinese diaspora in the future can be created. Starting from data from the first table, by using the mathematic formula:

$$
V_{l}=V_{p}(1+i)^{n}
$$

$9 \quad$ M. Đorđević and S. Stojiljković, (2013): „Ekonomska politika i javni dug u vreme globalne krize: preporuke vodećih ekonomista današnjice ", in Leković Vlastimir (eds.), Institucionalne promene kao determinanta privrednog razvoja Srbije, Ekonomski fakultet, Kragujevac, pp.245. 
Where is:

$V_{l}$ - population now or in the future

$V_{p}$ - population now or in the previous period

$i$ - annual growth rate

$n$ - number of years

It is possible to determine the data on the numerical strength of the Chinese diaspora in the future. By using the data from the previous table on the number of the representatives of the Chinese diaspora in the reporting period and by calculating the movement growth rate in the same period, the authors acquired the following data on the possible number and regional distribution of the Chinese diaspora in 2020 and 2025.

Table 3: Number of overseas Chinese in the World and by continent 2020 and 2025

\begin{tabular}{|l|c|c|}
\cline { 2 - 3 } \multicolumn{1}{c|}{} & $\mathbf{2 0 2 0}$ & $\mathbf{2 0 2 5}$ \\
\hline Asia & $19.461,4$ & $14.433,7$ \\
\hline America & $11.954,9$ & $14.856,2$ \\
\hline Europe & $2.108,3$ & $2.161,1$ \\
\hline Oceania & $1.709,9$ & $2.353,1$ \\
\hline Africa & 950,7 & 2001,6 \\
\hline Total( World) & $36.185,2$ & $35.805,7$ \\
\hline
\end{tabular}

Calculated by the authors

The data shows a declining trend of the Chinese diaspora in the world in the near future. A significant decline in influx of the representatives of the Chinese diaspora will be in Asia and Europe, while other parts of the world (the USA, Oceania and Africa) will see an increased influx.

\section{Chinese Diaspora in Serbia}

The first historical data on the meeting of Serbs with the Chinese and their culture is from the $18^{\text {th }}$ century and is part of the travel literature of that time..$^{10} \mathrm{~A}$ more intense economic relationship between these two countries started developing in the beginning of the 1990s, in the time of the greatest political and macroeconomic instability of the newly founded Federal Republic of Yugoslavia. At that time, a large number of the Chinese immigrated to Serbia and started business activities, mainly in the trading and hospitality sector. The data on the number of the Chinese residents who live in Serbia varies depending on the source and the purpose. According to the Business Registers Agency, In 2017,

10 J. Dučić, (1982): Grof Sava Vladislavić. Slovo ljubve, Beograd 
7.031 Chinese business entities were registrated in Serbia, ie those that have a Chinese owner or representative, and out of that number, 3.198 (45\%) are active, while the rest $(55 \%)$ have been deleted from the register or are in the process of liquidation. ${ }^{11}$ Most of active firms operate in the trade sector.

It is assumed that there are many more representatives of the Chinese diaspora and that many of them perform economic activities in the informal sector, ie the gray economy zone. The media have high free estimates of the number of Chinese in Serbia reaching incredible numbers, up to 100,000. According to Chen Hong, President of the Association of Chinese Citizens in Serbia, most of the Chinese people live in New Belgrade, near the Chinese shopping center in Block 70, where there is an open mall and where they perform commercial activities, but they also live and work in all other cities in Serbia. ${ }^{12}$ In addition to trade, Chinese people are also present in the catering industry and the agricultural sector. In the period of the economic crisis in Serbia, which lasted from the beginning of transition in different areas and intensities, many socially vulnerable families have survived thanks to cheap and affordable Chinese products. However, in the last years, the number of the Chinese citizens in Serbia has declined significantly. A small trading business is almost completely superseded by Chinese malls, based on former department stores.

Serbia can learn a great many from China, especially when it comes to attitudes towards the diaspora and the diaspora towards the homeland. On the other hand, the experiences of the Chinese diaspora which has been present in Serbia for a longer period of time, allow for a different perspective on all disadvantages of the economic system. Based on this, Serbia can draw useful suggestions on how to improve its economic environment and business climate in order for an increasing number of its diaspora to have a motivation and interest to return, if not for real, then at least virtually.

\section{Methodology}

The contribution of diaspora representatives to the economic development of their country may be significant, but it depends on many factors: those relating to the initial motivation for emigration, which can be political, economic, security and other, to those more complex ones that include the homeland's relation to their diaspora and different countries and parts of the world where the diaspora is located. The research included semi-structured interview in English language in order to provide general profile and to reveal the views of the aver-

\footnotetext{
11 https://www.ekapija.com/news/1880336/u-srbiji-aktivno-3198-kineskih-firmi-najvecibroj-posluje-u-sektoru-trgovine

12 I. Đorđević, (2006): “Chinesen in Serbien - (un)erwünschteGäste”. Ost-West.Europäische Perspektiven, 7(2), pp. 117-118.
} 
age representative of the Chinese diaspora in Serbia as well as business environment and business opportunities. The research involved 52 representatives of the Chinese diaspora in Serbia (thirty from the area of Belgrade, eleven from Vojvodina and ten from the south of Serbia) who are employed in trade, catering, industrial companies and the education sector. The research was conducted in the period from June to December 2017.

Respondents come from different areas of southeastern China. Most of them are from Zhejiang Province, then from Guangdong Province, three are from Fujian Province and one from Sichuan Province. These areas were marginal to the Chinese state, in terms of resource base. ${ }^{13}$ In relation to gender, the sample consists of 27 female and 35 male respondents. When it comes to professional qualification of the respondents, most of respondents have completed their secondary school (35 respondents), while 15 of them finished collage, and 2 respondents have a university degree in the fields of polytechnic science and philology.

Research questions for interview were designed in a simple and comprehensible way. The study covered only those issues that reveal the position and attitude of the Chinese diaspora in Serbia towards the country of origin. In addition, research instrument consists of questions that give insight in the specific aspects of that relationship (economic, social) and that group of questions that reveal the perceptions of the Chinese diaspora about the business environment and opportunities for business development in Serbia.

\section{Results and discussion}

The results obtained through semi-structured interview were presented in Table 4 in order to present the quality of life of the Chinese diaspora in Serbia and to show the existence of economic elements in their relationship with the homeland.

Table 4: Reuslts of the interview

\begin{tabular}{|c|c|c|c|c|}
\hline \multicolumn{5}{|c|}{ Have you been working in Serbia for more than five years? } \\
\hline Yes & No & Undefined & Total & in $\%$ \\
\hline 46 & 6 & - & 52 & 100 \\
\hline \multicolumn{5}{|c|}{ Does the work you do fit your qualifications? } \\
\hline Yes & No & Undefined & Total & in $\%$ \\
\hline 37 & 12 & 3 & 52 & 100 \\
\hline \multicolumn{5}{|c|}{ Was it difficult to start a business in Serbia? } \\
\hline Yes & No & Undefined & Total & in $\%$ \\
\hline 11 & 36 & 5 & 52 & 100 \\
\hline
\end{tabular}

$13 \quad$ R. Skeldon, (2007): “The Chinese Overseas: The End of Exceptionalism?”, in Thunø, Mette (eds), Beyond Chinatown: New Chinese Migration and the Global Expansion of China, UK: NIAS Press, pp.36 


\begin{tabular}{|c|c|c|c|c|}
\hline \multicolumn{5}{|c|}{ Are there any opportunities to develop your business in Serbia? } \\
\hline Yes & No & Undefined & Total & in $\%$ \\
\hline 9 & 37 & 2 & 48 & 92 \\
\hline \multicolumn{5}{|c|}{ Is your income big enough for living in Serbia? } \\
\hline Yes & No & Undefined & Total & in $\%$ \\
\hline 43 & 7 & 2 & 52 & 100 \\
\hline \multicolumn{5}{|c|}{ Is your income allowing you to send part of your earnings to China? } \\
\hline Yes & No & Undefined & Total & in $\%$ \\
\hline 27 & 25 & - & 52 & 100 \\
\hline \multicolumn{5}{|c|}{ Do you have and maintain business contacts with your home country? } \\
\hline Yes & No & Undefined & Total & in $\%$ \\
\hline 12 & 37 & 3 & 52 & 100 \\
\hline \multicolumn{5}{|c|}{ Have you traveled to China because of business for the duration of your stay in Serbia? } \\
\hline Yes & No & Undefined & Total & in $\%$ \\
\hline 11 & 41 & - & 52 & 100 \\
\hline \multicolumn{5}{|c|}{ Is there a company in China that you are investing in? } \\
\hline Yes & No & Undefined & Total & in $\%$ \\
\hline 9 & 43 & - & 52 & 100 \\
\hline \multicolumn{5}{|c|}{ Is it a family business? } \\
\hline Yes & No & Undefined & Total & in $\%$ \\
\hline 9 & 43 & - & 52 & 100 \\
\hline \multicolumn{5}{|c|}{ Does the amount of investments annually exceed the amount of 10,000 euro? } \\
\hline Yes & No & Undefined & Total & in $\%$ \\
\hline 2 & 39 & 11 & 52 & 100 \\
\hline \multicolumn{5}{|c|}{$\begin{array}{l}\text { Do you cooperate with your compatriots and do you, as a community, have some kind of } \\
\text { economic cooperation with your country of origin? }\end{array}$} \\
\hline Yes & No & Undefined & Total & in $\%$ \\
\hline- & 51 & 1 & 52 & 100 \\
\hline
\end{tabular}

The results of the research showed that almost $88 \%$ of respondents have lived in Serbia for more than five years. About $69 \%$ of them have not had major problems in Serbia, while 11\%, as a major lack of business in Serbia state complicated administration, long period between the submission of certain documents and obtaining a license, high rental price, difficulty in finding appropriate locations and facilities for business, etc. Almost $70 \%$ of the Chinese Diaspora representatives in Serbia are satisfied with the fact that the work they do corresponds to their qualifications, while this is not true for $23 \%$. They come from China to earn money in new markets where there is high demand for cheap products, and most of them are not planning to stay longer in Serbia or in the region. Their new target markets are Latin and South America (Brazil, Argentina, etc.). The following is another picture regarding business development opportunities currently taking place in Serbia: 77\% believe that the development of business con- 
ditions does not exist (this percentage is the answer of the respondents working in trade, education while those who own a Chinese restaurant consider that in this market, business opportunities have reached the maximum and that further improvement and development of business in these conditions is not possible.

Most respondents are satisfied with the wages in Serbia, but only $51 \%$ of them send their salaries to their home country, and $49 \%$ do not. Those who send money to China mostly send money to their families, part of a family business, and their remittances are important for maintaining economic ties with their homeland. Only $23 \%$ of the money earned in Serbia is sent to their families and used to develop small businesses that are their own, and mainly deal with the services of the industry: trade, transport, catering in terms of food production, and even some activities such as maintenance or care and beauty services. Only two respondents can send 10,000 euros or more per year to their homeland. This makes only $3.8 \%$ of the total number of respondents, or $9 \%$ of those who respond positively to the question of whether they send part of their salaries to China. They are employed in large industrial companies. Others, who are willing to send smaller sums of money to their homeland, work in other above-mentioned activities, mostly in trade. Representatives of the Chinese diaspora in Serbia who participated in the research and interview have no connection and cooperation with their compatriots in Serbia, nor do they perform any form of joint engagement when it comes to investing in the country of origin.

In terms of positive experiences that China has with its diaspora and possibilities to transfer these experiences to Serbia and its diaspora, the respondents generally noted that these two countries are incomparable in terms of the territory occupied and the size of the population and diaspora. Given that the economic standard and lack of opportunities for professional development and promotion are the main motive for constant increase of the Serbian diaspora, the respondents' opinion is that Serbia should achieve economic stability, and in terms of business conditions, apply positive experiences from the countries of Western Europe and those countries where there are most representatives of the diaspora.

When respondents were asked how they perceive the economic and social environment in Serbia, and what they would give as recommendation, the most common answers were the following: tax incentives for small and medium enterprises, reduction of employers' obligations for their employees, i.e. the implementation of benefits for every employee so that employers would have an interest in registering employees in a lawful manner (in essence, this response, according to author's assessment, is the idea that the government, in the same way as it stimulates the creation of new jobs in the case of foreign companies, should also stimulate startup businesses of residents, creating new jobs in existing small and medium-sized private enterprises: such incentives may include a wide range of measures, from donations from the budget to tax incentives for employers). All respondents stated they did not have any problems based on racial or religious affiliation. The perception of the Serbian population, that is, the working age of this population, is that it 
lacks the initiative and courage to start its own business, that the state's support is lacking in that respect, and the general attitude is that people in Serbia should work more and deal less with political issues.

\section{Conclusion}

Interviewed representatives of the Chinese Diaspora do not recognize Serbia as a very profitable business destination. Most of them see their stay in Serbia as temporary and dependent on economic conditions in particular. They all keep links with China, through the visits their relatives and family and remittances. They have no objections to the social environment in Serbia - they feel accepted by the local population in parts of the country where they live and work. They have remarks on the economic situation in Serbia, the lower standard of the population, the lower possibility for earning money, which forces them to continue their business activities in other markets. In their opinion, the government should take all measures that can lead to a more favorable business climate: simpler administrative procedures, more flexible tax policies, employer incentives, especially when hiring new workers, etc. Respondents also note that the labor force in Serbia does not use its potential and shows low level of initiative to start its own business.

The basis of their proposal to improve the economic standard in Serbia and its relationship with the diaspora is to set the focus away from politics to business and to create a more stable economic environment. In terms of creating more attractive business conditions, their view is that Serbia should look for some good examples from around the world, especially Europe, which is geographically close and where most of the Serbian diaspora is concentrated.

\section{Literature}

- Agencija za privredne registre Serbia (Serbia Business Registers Agency), Available at: http://www.apr.gov.rs/eng/Home.aspx.

- Biao, Xiang (2003). „Emigration from China: A Sending Country Perspective “. International Migrations, 41(3), 21-48. UN International Organization for Migration. DOI 10.1111/1468-2435.00240.

- Dučić, Jovan (1982): Grof Sava Vladislavić. Slovo ljubve, Beograd

- Đorđević, Ivan (2006). "Chinesen in Serbien - (un)erwünschte Gäste”. OstWest. Europäische Perspektiven, 7(2), 115-122.

- Đorđević, Miroslav and Stojiljković, Sonja (2013). „Ekonomska politika i javni dug u vreme globalne krize: preporuke vodećih ekonomista današnjice“. In Leković Vlastimir (Ed.), Institucionalne promene kao determinanta privrednog razvoja Srbije (pp. 243-258). Ekonomski fakultet, Kragujevac 
- E-kapija portal, https://www.ekapija.com/news/1880336/u-srbiji-aktivno3198-kineskih-firmi-najveci-broj-posluje-u-sektoru-trgovine

- Hsing, You-tien (2003): "Ethnic identity and business solidarity: Chinese capitalism revisited", in L. J. C. Ma, and C. Cartier (eds), The Chinese Diaspora: Space, place, mobility and identity. Boulder, Colorado: Rowman and Littlefield, pp. 221-235.

- International Organization for Migrations, Migrations Initiative 2016, https://publications.iom.int/system/files/migration_initiatives2016.pdf;

- Iredale, R. Robyn and Guo, Fei (2015). Handbook of Chinese Migration. Edward Elgar Publishing Limited, Cheltenham, Glos, UK.

- Mitrović, Dragana (2008). Kinesko ekonomsko čudo - prva dekada reformi. IPS, Beograd.

- National Bureau of Statistics of China, Rural-Urban Migration Monitoring Survey, 2014.

- Pan, Lynn (1994). Sons of the Yellow Emperor: A History of the Chinese Diaspora. Kodansha America, New York.

- Pan, Lynn (2006). The Encyclopedia of the Chinese Overseas, Singapore: Didier Millet edition.

- Pastore, Ferruccio and Castagnone, Eleonora (2011): „Studiare L' Imprenditoria Cinese Oltre i Luoghi Comuni. In Camera di Commercio in Torino ", Diventare Laoban: Lavoro Autonomo Percorsi Imprenditoriali e Progetti Migratori dei Cinesi in Italia e a Torino, 3-15. Camera di Commercio, Torino.

- Poston L. Dudley and Yu Mei-Yu (1992): „The Distribution of Overseas Chinese ", in Poston, L. Dudley and D. Yaukey (1992): The Population of Modern China. Springer Science \& Business Media, New York, pp.117-148.

- Poston, L. Dudley and Wong, Juyin (2016). “The Chinese Diaspora: The Current Distribution of the Overseas Chinese Population”. Chinese Journal of Sociology 2(3), 348-373. DOI: 10.1177/2057150X16655077

- Shixu Gui (2011). „The contribution of overseas Chinese to China's development “. In Qu, Jin, Zhang, Yudong, Luo, Kereng and Li, Minghuan (Eds.), Annual Report on Overseas Chinese Studies (pp. 51-84). Social Sciences Academic Press, Beijing

- Simić, Predrag (2003). Kina: kratka istorija, Nea, Beograd.

- Skeldon, Ronald (2007). "The Chinese Overseas: The End of Exceptionalism?” In Thunø, Mette (Ed.), Beyond Chinatown: New Chinese Migration and the Global Expansion of China (pp.35-48). UK: NIAS Press.

- UN International Migration Report 2018: Highlights, United Nations 2019.

- World Economic Forum, https://www.weforum.org/agenda/2016/01/whichcountry-has-the-largest-diaspora/ available on February, 2019

- Zhou, Min and Benton, Gregor (2017). "Intra-Asian Chinese Migrations: A Historical Overview”, in Zhou Min (eds), Contemporary Chinese Diasporas (pp.1-25). Palgrave Macmillan, UK. 
DOI: 10.5937/MegRev2103267B

Originalni naučni rad

Primljen 20.11.2020.

Odobren 18.12.2020.

\title{
KINESKA DIJASPORA U SRBIJI
}

\begin{abstract}
Abstrakt. Cilj ovog rada je bolje razumevanje iskustava dela kineske dijaspore koji živi $i$ radi u Srbiji, njihove percepcije Srbije kao zemlje destinacije i njihovog doživljaja ekonomskog okruženja i kvaliteta života u Srbiji. Istraživanje je sprovedeno u periodu od juna do decembra 2017. Godine, a obuhvatilo je 52 predstavnika kineske dijaspore u Srbiji. Kao metoda istraživanja korišćen je polustrukturisani intervju. Rezultati pokazuju da predstavnici kineske dijaspore ne prepoznaju Srbiju kao veoma povoljnu poslovnu destinaciju $i$ većina njih svoj boravak u Srbiji vidi kao privremen i zavisan od ekonomskih uslova.
\end{abstract}

Ključne reči: kineska dijaspora, Srbija, iskustva dijaspore, odnosi sa domovinom. 